Varga, Zsuzsanna. "Selected English-Language Bibliography of Interest for Hungarian Cultural Studies: 20182019." Hungarian Cultural Studies. e-Journal of the American Hungarian Educators Association, Volume 12 (2019) DOI: 10.5195/ahea.2019.366

\title{
Selected English-Language Bibliography of Interest for Hungarian Cultural Studies: 2018-2019
}

\section{Zsuzsanna Varga}

\begin{abstract}
As the above title indicates, because of the publication schedule of Hungarian Cultural Studies this bibliography straddles 2018-2019, covering the period since the publication in Fall of 2018 of last year's bibliography in this journal. Each year's bibliography may also be supplemented by earlier items, which were retrieved only recently. Although this bibliography series can only concentrate on English-language items, occasional items of particular interest in other languages may be included. For a more extensive bibliography of Hungarian Studies from about 2000 to 2010, for which this is a continuing update, see Louise O. Vasvári, Steven Tötösy de Zepetnek, and Carlo Salzani. "Bibliography for Work in Hungarian Studies as Comparative Central European Studies." CLCWeb: Comparative Literature and Culture (Library) (2011): http://docs.lib.purdue.edu/clcweblibrary/hungarianstudiesbibliography.
\end{abstract}

Biography: Zsuzsanna Varga studied English, Hungarian and Portuguese language and literature at Eötvös Loránd University, Budapest. She took her $\mathrm{PhD}$ in $19^{\text {th }}$ century English literature at Edinburgh University. She has taught and researched at different British universities, including the University of Essex, UCL and De Montfort University. She has taught Hungarian Studies at Glasgow University since 2008, and she is also in charge of the Hungarian library collection at the University of Oxford. Her research interests include $19^{\text {th }}$ century women's writing, travel writing and translation history.zsuzsanna.varga@glasgow.ac.uk

Aczel, Richard. 2016. "Hungarian Romanticism: Reimagining (Literary) History." The Oxford Handbook of European Romanticism. Ed. Paul Hamilton. Oxford: Oxford UP. Adobati, Mario. 2018. "The Hungarian Post-Communist Black Series (1956-2012): A Preparatory Sketch about the Historical Times' Structure.” Hungarian Studies 32.1: 131-144.

Akinsha, Konstantin. 2011. "Lunching under the Goya. Jewish Collectors in Budapest at the Beginning of the Twentieth Century." Quest. Issues in Contemporary Jewish History 2 http://www.quest-cdecjournal.it/focus.php?issue=2\&id=231

Albert, Fruzsina, Beáta David, Zoltán Kmetty, Luca Kristóf, Péter Róbert, and Andrea Szabó. 2018. "Mapping the Post-Communist Class Structure: Findings from a New Multidimensional Hungarian Class Survey.” East European Politics, Societies and Cultures 32.3: 544-565.

Apor, Péter. 2018. "Hungary". The Handbook of COURAGE: Cultural Opposition and Its Heritage in Eastern Europe. Eds. Balázs Apor, Péter Apor and Sándor Horváth. Budapest: HAS: $137-150$. 
Varga, Zsuzsanna. "Selected English-Language Bibliography of Interest for Hungarian Cultural Studies: 20182019." Hungarian Cultural Studies. e-Journal of the American Hungarian Educators Association, Volume 12 (2019) DOI: $10.5195 /$ ahea.2019.366

Apor, Péter, Josip Mihaljević and Cristina Petrescu. 2018. "Collections of Intellectual Dissent: Historians and Sociologists in Post-1968 Hungary, Romania and Yugoslavia." The Handbook of COURAGE: Cultural Opposition and Its Heritage in Eastern Europe. Eds. Balázs Apor, Péter Apor and Sándor Horváth. Budapest: HAS: 369-390.

Asztalos-Morell, Ildikó. 2018. "The Agency of Roma Women's NGO in Marginalised Rural Municipalities in Hungary.” In Gendering Postsocialism: Old Legacies and New Hierarchies. Eds. Ildikó Asztalos-Morell and Julia Gradskova. London: Routledge: 121138.

Asztalos-Morell, Ildikó. 2016. "Poverty and Governance: Rural Municipal Strategies Facing Ethnic and Social Marginalisation and Long-Term Unemployment in Hungary." The Uppsala Yearbook of Eurasian Studies. Uppsala: Uppsala Universitet: 183-211.

Bakucs, Zoltán; Imre Fertő, Ágnes Varga, and Zsófia Benedek. 2018. "Impact of European Union Development Subsidies on Hungarian Regions." European Planning Studies 26.6: $1121-1136$.

Balatonyi, Judit. 2018. "From Deviancy to Norm: An Alternative Betrothal Rite in Gyimes." Acta Ethnographica Hungarica 63.1:33-48.

Balogh, Róbert. 2018. "Was There a Socialist Type of Anthropocene During the Cold War? Science, Economy, and the History of the Poplar Species in Hungary, 1945-1975." Hungarian Historical Review 7.3: 594-624.

Bárt, Dániel. 2018. "Exorcism and Sexuality: The "Thick Description" of an $18^{\text {th }}$-Century Transylvanian Catholic Priest's Transgression.” Acta Ethnographica Hungarica 63.1: 107128.

Blair, Kirstie. 2018. "'Whose Cry is Liberty, and Fatherland': Kossuth, Garibaldi and European Nationalism in Scottish Political Poetry." Scottish Literary Review 10. 2: 71-94.

Bogdándi, Zsolt. 2018. "The Organization of the Central Court of Justice in Transylvania in the Second Half of the Sixteenth Century." Hungarian Historical Review 7.4: 718-738.

Bollobás, Enikő. 2018. "Versions of Triangular Desire in Hungarian Literature: Reading Sándor Márai and Péter Nádas. "Hungarian Cultural Studies 11: 48-56. https://ahea.pitt.edu/ojs/index.php/ahea/article/view/321

Bot, Ioana. 2018. "The "Darling Emperor": Images of the Austro-Hungarian Monarchy in the Romanian Folklore from Transylvania around WWI." Neohelicon: Acta Comparationis Litterarum Universarum 45.1: 113-121.

Bozóki, András and Daniel Hegedűs. 2018. "An Externally Constrained Hybrid Regime: Hungary in the European Union." Democratization 25.7: 1173-1189.

Brown, Alexander. 2018. "In Defence of Reason: Friedrich Nietzsche in Thomas Mann's Nietzsches Philosophie im Lichte unserer Erfahrung und Georg Lukács's Die Zerstörung der Vernunft." Nietzsche Studien: Internationales Jahrbuch für die Nietzsche-Forschung, 47: 379-397.

Brown, Karl. 2018. "The Spirit of the Radio: Hungary 1956, Radio Free Europe, and the Shadow Public Sphere." Hungarian Cultural Studies 11: 89-103.

https://ahea.pitt.edu/ojs/index.php/ahea/article/view/324

Brown, Karl. 2012. "The Extraordinary Career of Feketevágó Úr: Wood Theft, Pig Killing and Entrepreneurship in Communist Hungary, 1948-1956." Communism Unwrapped: Cultures of Consumption in Postwar Eastern Europe. Eds. Paulina Bren and Mary Neuburger. Oxford: Oxford UP. 
Varga, Zsuzsanna. "Selected English-Language Bibliography of Interest for Hungarian Cultural Studies: 20182019." Hungarian Cultural Studies. e-Journal of the American Hungarian Educators Association, Volume 12 (2019) DOI: $10.5195 /$ ahea.2019.366

Bryant, Chad. 2018. "Habsburg History, Eastern European History ... Central European History?" Central European History 51.1: 56-65.

Burkhart, Dagmar. 2018. "The Concept of "Bare Life" in Camp Literature." Frontiers of Narrative Studies 4.1: 133-139.

Callaway, James. 2018. "The Battle over Information and Transportation: Extra-European Conflicts between the Hungarian State and the Austro-Hungarian Foreign Ministry." Hungarian Historical Review 7.2: 274-302.

Courtman, Nicholas. 2018. "Seeing the Human in the (Queer) Migrant in Jenny Erpenbeck's Gehen, Ging, Gegangen and Terézia Mora's Alle Tage." Queering German Culture. Ed. Leanne Dawson. Rochester, NY: Camden House: 153-176.

N, Csurgó, Bernadett, Csongor Jánosi, Katalin Juhász, Vladas Sirutavičius, Corneliu Pintilescu. 2018. "Folklore Revivalism and Ethnography: Alternatives to Everyday Culture." The Handbook of COURAGE: Cultural Opposition and Its Heritage in Eastern Europe. Eds. Balázs Apor, Péter Apor and Sándor Horváth. Budapest: HAS: 573-602.

Danyi, Gábor. 2019. The Typewriter and the Travelling Bag: Samizdat Literature in the Kádár Era (1956-1986) Ph.D. Dissertation. Eötvös Loránd University, Budapest.

Deak, John. 2018. "Habsburg Studies within Central European History: The State of the Field." Central European History 51.1: 53-55.

Egry, Gábor. 2017. "Armed Peasants, Violent Intellectuals and Political Guards: Trajectories of Violence in a Failing Nation State, 1918-1940." Stred-Centre 9.1: 34-54.

Egry, Gábor. 2017. "The World between Us: State Security and the Negotiation of Social Categories in Interwar Romania." East Central Europe / L'Europe du Centre Est. 44.1: 1746.

Egry, Gábor. 2015. "A Fate for a Nation: Concepts of History and the Nation in Hungarian Politics, 1989-2010." Thinking Through Transition: Liberal Democracy, Authoritarian Pasts, and Intellectual History in East Central Europe After 1989. Eds. Michal Kopecek and Piotr Wcislik. Budapest-New York: CEU Press: 505-524.

Fehér, Andrea. 2018. "From Courtship till the Morning After: The Role of Family, Kin and Friends in the Marriages of László Székely." Hungarian Historical Review 7.4: 785-804.

Fejér, Tamás. 2018. "Formularies of the Chancellery of the Transylvanian Principality in the Second Half of the Sixteenth Century." Hungarian Historical Review 7.4: 739-759.

Gálfi, Emőke. 2018. "The Society of the Residence of the Transylvanian Princes in the Second Half of the Sixteenth Century." Hungarian Historical Review 7.4: 760-784.

Gantner, Eszter. 2018. "Linking Emerging Cities—Exchange between Helsinki and Budapest at the Beginning of the Twentieth Century." Journal of East Central European Studies 67.4: $507-521$.

Gelencsér, Gábor. 2018. "The Zones of Twilight: Son of Saul and the Tradition of Holocaust Representation in Hungarian Full-Length Feature Films.” Apparatus: Film, Media and Digital Cultures in Central and Eastern Europe 7 http://www.apparatusjournal.net/index.php/apparatus/article/view/26/376

Gerő, Márton and Gábor Hajdú. 2018. "The Size and Heterogeneity of Egocentric Networks and Social Integration in Hungary." East European Politics and Societies and Cultures 32.4: 845-865. 
Varga, Zsuzsanna. "Selected English-Language Bibliography of Interest for Hungarian Cultural Studies: 20182019." Hungarian Cultural Studies. e-Journal of the American Hungarian Educators Association, Volume 12 (2019) DOI: $10.5195 /$ ahea.2019.366

Gerstenberger, Katharina. 2018. "Post-1989 Geographies in Terézia Mora's Der einzige Mann auf dem Kontinent and Das Ungeheuer." German Life and Letters, 71.3: 291-307.

Goderle, Wolfgang. 2018. "State-Building, Imperial Science, and Bourgeois Careers in the Habsburg Monarchy in the 1848 Generation: The Cases of Karl Czoernig (1804-1889) and Carl Alexander von Hugel (1795/96-1870)." Hungarian Historical Review 7.2: 222-249.

Gombocz, Katarina. 2016. "They Gave Hungary Away": Depression and Traumatic Cultural Identity Among Hungarians. MA Thesis Western Washington University.

Görözdi, Judit. 2018. "The Body of History on Parallel Stories, the Novel by Péter Nádas." Hungarian Studies 32.1: 91-100.

Gremels, Andrea and Maren Scheurer. 2018. "Intentionally Left Blank: The Empty Page between Signification and Silence." Comparatio: Zeitschrift für Vergleichende Literaturwissenschaft 10.1: 39-56.

Győrffy, Gábor, Zoltán Tibori-Szabó, Júlia-RékVallasek. 2018. "Back to the Origins: The Tragic History of the Szekler Sabbatarians.” East European Politics and Societies and Cultures. 32.3: 566-585.

Győrfy, Eszter. 2018. "They Spoke Hungarian but Were of a Romanian Faith.” A Greek Catholic Community in Székely Land in the First Half of the $20^{\text {th }}$ Century." Acta Ethographica Hungarica 63.1: 11-32.

Haarman, Daniela. 2018. "The Hungarian Language Issue in Hungary and Transylvania Before 1795." Yearbook of the Institute of History George Bariţiu in Cluj-Napoca, Series Historica 57: 385-402.

Hajdu, Péter. 2018. "The Collective in the Hungarian Narrative Tradition and Narrative Studies." Neohelicon: Acta Comparationis Litterarum Universarum 45.2: 431-443.

Halmai, Gábor. 2018. "Abuse of Constitutional Identity: The Hungarian Constitutional Court on Interpretation of Article E) (2) of the Fundamental Law." Review of Central and East European Law 43.1: 23-42.

Harms, Victoria. 2012. "Living Mitteleuropa in the 1980s: a Network of Hungarian and West German Intellectuals." European Review of History: Revue européenne d'histoire 19.5: 669-92.

Haslinger, Peter. 2018. "Dilemmas of Security: The State, Local Agency, and the Czechoslovak-Hungarian Boundary Commission, 1921-25.” Austrian History Yearbook 49.1: 187-206.

Havasréti, József, Sándor Horváth, Yvetta Kajanová, and Miroslav Michela. 2018. "Youth Cultures: Escape to Gospel Songs, Rock and Punk." The Handbook of COURAGE: Cultural Opposition and Its Heritage in Eastern Europe. Eds. Balázs Apor, Péter Apor and Sándor Horváth. Budapest: HAS: 391-414.

Hegyi, Géza. 2018. "Did Romanians Living on Church Estates in Medieval Transylvania Pay the Tithe?" Hungarian Historical Review 7.4: 694-717.

Hites, Sándor. 2018. "National Museum/National Library: Hungary.” Encyclopedia of Romantic Nationalism in Europe: Volumes 1-2. Ed. Joep Leerseen. Amsterdam: Amsterdam University Press: 366-368.

Hites, Sándor. 2018. “Commemorations, Festivals: Hungarian.” Encyclopedia of Romantic Nationalism in Europe. Volumes 1-2. Ed. Joep Leerseen. Amsterdam: Amsterdam UP: 480-483 
Varga, Zsuzsanna. "Selected English-Language Bibliography of Interest for Hungarian Cultural Studies: 20182019." Hungarian Cultural Studies. e-Journal of the American Hungarian Educators Association, Volume 12 (2019) DOI: $10.5195 /$ ahea.2019.366

Hites, Sándor. 2018. "Petőfi, Sándor.” Encyclopedia of Romantic Nationalism in Europe. Volumes 1-2. Ed. Joep Leerseen. Amsterdam: Amsterdam UP: 1049-1051.

Hites, Sándor. 2018. "Language Interest: Hungarian,” Encyclopedia of Romantic Nationalism in Europe. Volumes 1-2. Ed. Joep Leerseen. Amsterdam: Amsterdam UP: 1049-1051.

Hites, Sándor. 2018. “Text Editions: Hungarian.” Encyclopedia of Romantic Nationalism in Europe. Volume 1-2. Ed. Joep Leerseen. Amsterdam: Amsterdam UP: 1051-1054.

Hites, Sándor. 2018. "Dress, design: Hungarian.” Encyclopedia of Romantic Nationalism in Europe. Volumes 1-2. Ed. Joep Leerseen. Amsterdam: Amsterdam UP: 1059-1061.

Hites, Sándor. 2018. "Cultural Sociability: Hungary." Encyclopedia of Romantic Nationalism in Europe. Volumes 1-2. Ed. Joep Leerseen. Amsterdam: Amsterdam UP: 1064-1066.

Hites, Sándor. 2018. "Political and Cultural Nationalism: Hungary.” Encyclopedia of Romantic Nationalism in Europe. Volumes 1-2. Ed. Joep Leerseen. Amsterdam: Amsterdam UP: 1069-1071.

Hites, Sándor. 2018. "Publishing Ventures, Periodicals: Hungary." Encyclopedia of Romantic Nationalism in Europe. Volumes 1-2. Ed. Joep Leerseen. Amsterdam: Amsterdam UP: 1072-1073.

Hites, Sándor. 2018. "Universities, University Chairs: Hungary.” Encyclopedia of Romantic Nationalism in Europe. Volumes 1-2. Ed. Joep Leerseen. Amsterdam: Amsterdam UP: 1073-1075.

Hites, Sándor. 2018. “Jókai, Mór.” Encyclopedia of Romantic Nationalism in Europe. Volumes 1-2. Ed. Joep Leerseen. Amsterdam: Amsterdam UP: 1075-1077.

Hites, Sándor. 2018. "How to Begin and How to End National Narratives? Histories of Literature and Economic Thought in $19^{\text {th }}$ century Hungary." Festschrift for Péter Dávidházi. Eds. Dániel Panka, Natália Pikli andVeronika Ruttkay. Budapest: ELTE BTK: 163-170.

Hites, Sándor. 2017. "Rocking the Cradle: Making Petofi a National Poet," Arcadia 52.1: 29-50. Hites, Sándor. 2016. "On Monetary and Literary Fictions." Neohelicon 43.2: 427-443.

Hollósi, Gábor. 2018. "Symbol or Concept? An Overview of the Doctrine of the Holy Crown of Hungary." Hungarian Studies Review 45.1-2: 83-92.

Imre, Anikó. 2016. TV Socialism. Durham, N.C.: Duke UP.

Imre, Zoltán. 2013. "Operetta beyond Borders: The Different Versions of Die Csárdásfürstin in Europe and the United States (1915-1921)." Studies in Musical Theatre 7.2: 175-205.

Jelicic, Ivan. 2018. "The Typographers' Community of Fiume: Combining a Spirit of Collegiality, Class Identity, Local Patriotism, Socialism, and Nationalism(s)." Austrian History Yearbook 49.1: 73-86.

Kalmár, György. 2017. Formations of Masculinity in Post-Communist Hungarian Cinema: Labyrinthian Men. London: Palgrave Macmillan.

Kamusella, Thomas. 2009. The Politics of Language and Nationalism in Modern Central Europe. London: Palgrave Macmillan.

Kaps, Klemens. 2018. "Cores and Peripheries Reconsidered: Economic Development, Trade and Cultural Images in the Eighteenth-Century Habsburg Monarchy."

Hungarian Historical Review 7.2: 191-221.

Kenyeres, János. 2007. "[G]reat Stone on our Knees": Reflections of the Hungarian Revolution in World Literature. Hungarian Studies Review 34.1-2: 203-216. 
Varga, Zsuzsanna. "Selected English-Language Bibliography of Interest for Hungarian Cultural Studies: 20182019." Hungarian Cultural Studies. e-Journal of the American Hungarian Educators Association, Volume 12 (2019) DOI: $10.5195 /$ ahea.2019.366

Kiss, Ernő Csongor. 2018. "Herta Müller's Atemschaukel (The Hunger Angel) in the Context of Twentieth-Century Forced Migration in East-Central Europe." Hungarian Cultural Studies 11: 78-88. https://ahea.pitt.edu/ojs/index.php/ahea/article/view/323

Kiss, Gábor Farkas. 2018. "Konrad Celtis, King Matthias, and the Academic Movement in Hungary." Hungarian Studies 32.1: 37-50.

Kiss Tamás, István Gergő Székely, Tibor Toró, Nándor Bárdi and István Horváth. eds. 2018. Unequal Accommodation of Minority Rights: Hungarians in Transylvania. London: Palgrave Macmillan.

Kovács, András W. 2018. "The Participation of the Medieval Transylvanian Counties in Tax Collection." Hungarian Historical Review 7.4: 671-693.

Kovacs, Jason F. 2018. "The First Hungarian Settlements in Western Canada: Hun's Valley: Esterhaz-Kaposvar, Otthon, and Bekevar." Hungarian Studies Review 45.1-2: 5-20.

Kövér, György. 2018. "The Rothschild Consortium and the State Debt of the Austro-Hungarian Monarchy." Hungarian Historical Review 7.2: 250-273.

Kuna, Agnes. 2018. "Patterns of Persuasion in Hungarian Medical Discourse Domain from the 16th and 17th Centuries." Persuasion in Public Discourse: Cognitive and Functional Perspectives. Eds. Jana Pelclová, and Wei-Lun Lu. Amsterdam: John Benjamins: 21-42.

Kunt, Gergely. 2017. "Mapping the Intergenerational Memory of the Holocaust in Hungarian Bystander Families: The Case of Sacha Batthyány’s Identity Novel, Und was hat es mit mir zu tun? [And What Does That Have to Do with Me?] Hungarian Cultural Studies 10: 54-67. https://ahea.pitt.edu/ojs/index.php/ahea/article/view/279

Kurucz, György. 2018. "Maria Theresa's Urbarial Patent: Royal Conscience and Enlightened Habsburg Economic Policy.” Hungarian Studies 32.2: 263-272.

Laszlovszky, József, Stephen Pow, Beatrix F. Romhányi, László Ferenczi and Zsolt Pinke. 2018. "Contextualizing the Mongol Invasion of Hungary in 1241-42: Short- and Long-Term Perspectives." Hungarian Historical Review 7.3: 419-450.

Lazaroms, Ilse Josepha. 2019. "As the Old Homeland Unravels: Hungarian-American Jews' Reactions to the White Terror in Hungary, 1919-24." Austrian History Yearbook 50: 150-165.

Lazaroms, Ilse Josepha. 2018. "Local Faces, Human Crimes--New Histories of the Hungarian Holocaust." East Central Europe 45.1: 119 -127.

Lemmen, Sarah. 2018. "The Formation of Global Tourism from an East-Central European Perspective." Hungarian Historical Review. 7.2: 348-374.

Livezeanu, Irina with June Pachuta Farris. 2007. Women and Gender in Central and Eastern Europe, Russia and Eurasia: a Comprehensive Bibliography. Volume 1. Armonk and London: M.E. Sharpe.

Magyar, Bálint. 2019. "Parallel System Narratives_Polish and Hungarian Regime Formations Compared." Stubborn Structures Reconceptualizing Post-Communist Regimes. Ed. Bálint Magyar. Budapest: CEU Press: 611-654.

Magyar, Bálint. 2019. "From Free Market Corruption Risk to the Certainty of a State-Run Criminal Organization (using Hungary as an Example).” Stubborn Structures Reconceptualizing Post-Communist Regimes. Ed. Bálint Magyar. Budapest: CEU Press. Ed. Bálint Magyar. Budapest: CEU Press: 461-488. 
Varga, Zsuzsanna. "Selected English-Language Bibliography of Interest for Hungarian Cultural Studies: 20182019." Hungarian Cultural Studies. e-Journal of the American Hungarian Educators Association, Volume 12 (2019) DOI: $10.5195 /$ ahea.2019.366

Manchin, Anna. 2010. "Interwar Hungarian Entertainment Films and the Reinvention of Rural Modernity." Rural History 21.2: 195-212

Mark, James and Péter Apor. 2015. "Socialism Goes Global: Decolonization and the Making of a New Culture of Internationalism in Socialist Hungary, 1956-1989." Journal of Modern History 87.4: 852-91.

Molnár, Dávid. 2018. "On the Innocence of Historiography: Johannes Sambucus' Emblem about the Difference between Grammar, Dialectics, Rhetoric, and History." Hungarian Studies 32.1: 27-36.

Mano, Miho, Yuko Yoshinari, Kiyoko Eguchi. 2018. "The Effects of the First Language on the Description of Motion Events: Focusing on L2 Japanese Learners of English and Hungarian." New Perspectives on the Development of Communicative and Related Competence in Foreign Language Education. Eds. Izumi Walker, Daniel Chan, Masanori Nagami and Claire Bourguignon. Berlin: de Gruyter: 125-156.

Mellis, Johanna. 2019. “Cold War Politics and the California Running Scene: The Experiences of Mihály Iglói and László Tábori in the Golden State." Journal of Sport History 46.1 62- 81.

Mevissen, Robert Shields. 2018. "Meandering Circumstances, Fluid Associations: Shaping Riverine Transformations in the Late Habsburg Monarchy." Austrian History Yearbook 49.1: $23-40$.

Miller, Tyrus. 2018. "Modernist Literature and Politics." The Bloomsbury Companion to Modernist Literature. Eds. Ulrika Maude and Mark Nixon. London: Bloomsbury Academic: 375-391.

Mitchievici, Angelo. 2018. "Decadence of an Empire: War, Heroism and Derision.” Neohelicon: Acta Comparationis Litterarum Universarum 45.1: 83-95.

Mulligan, William and Jack S. Levy. 2019. "Rethinking Power Politics in an Interdependent World, 1871-1914.” Journal of Interdisciplinary History 49.4: 611-640.

Munteán, László. 2018. "Plaster Archeology in Budapest's Seventh District: Toward a Mode of Engagement with Architectural Surfaces.” Hungarian Cultural Studies 11: 11-22. https://ahea.pitt.edu/ojs/index.php/ahea/article/view/319

Nagy, Zsolt. 2017. Great Expectations and Interwar Realities: Hungarian Cultural Diplomacy 1918-1941. Budapest: CEU Press.

Németh, Boglárka and Anna Sörés. 2018. "Evaluative Morphology in the Verbal Domain: Complex Verbs Suffixed with -kVdik in Hungarian." Studies in Language: International Journal Sponsored by the Foundation "Foundations of Language" 42.1: 202-225.

Newman, John Paul and Tamara Scheer. 2019. "The Ban Jelacic Trust for Disabled Soldiers and Their Families: Habsburg Dynastic Loyalty beyond National Boundaries, 184951." Austrian History Yearbook 49.1: 152-165.

Nicholls, Angus. 2018. "The 'Goethean' Discourses on Weltliteratur and the Origins of Comparative Literature: The Cases of Hugo Meltzl and Hutcheson Macaulay Posnett." Seminar: A Journal of Germanic Studies 54.2: 167-194.

Niessen, James P. 2018. "Heritage and Repatriation in the History of Habsburg and Hungarian Archives." Hungarian Cultural Studies 11: 136-143. https://ahea.pitt.edu/ojs/index.php/ahea/article/view/327 
Varga, Zsuzsanna. "Selected English-Language Bibliography of Interest for Hungarian Cultural Studies: 20182019." Hungarian Cultural Studies. e-Journal of the American Hungarian Educators Association, Volume 12 (2019) DOI: $10.5195 /$ ahea.2019.366

Nyirady, Kenneth. 2018. "Libel or Not? The War of Words between Lajos Kossuth and New York Editor James Watson Webb." Hungarian Cultural Studies 11: 1-10. https://ahea.pitt.edu/ojs/index.php/ahea/article/view/317

Orzóy, Ágnes. 2018. "Reading Ádám Bodor's Sinistra körzet ('The Sinistra Zone') in English." Hungarian Cultural Studies 11: 104-119. https://ahea.pitt.edu/ojs/index.php/ahea/article/view/325

Pál, József. 2018. "On the Ethos of the Austro-Hungarian Monarchy." Neohelicon: Acta Comparationis Litterarum Universarum, 45.1: 1-15.

Palonen, Emilia. 2012. "Transition to Crisis in Hungary: Whistle-Blowing on the Naked Emperor." Politics and Policy 40.5: 930-957.

Parapatics, Andrea. 2018. "On Hungarian Slang: Changing Functions and Attitudes." Jugendsprachen/Youth Languages: Aktuelle Perspektiven internationaler Forschung/Current Perspectives of International Research. Volumes 1-2. Ed. Arne Ziegler. Berlin: de Gruyter: 681-706.

Pastor, Peter. 2018. "The Travelogues of Gyula Illyés and Lajos Nagy on Their Visit to the Soviet Union."Hungarian Cultural Studies 11: 32-47.

https://ahea.pitt.edu/ojs/index.php/ahea/article/view/320

Peterecz, Zoltán. 2018. "Immediate Post-World War I Hungary through the Eyes of an American." Hungarian Studies 32.2: 305-318.

Peti, Lehel. "Migration and Pentecostalism in a Mendicant Roma Community in Eastern Moldavia." Acta Ethnographica Hungarica 63.1: 83-106.

Piahanau, Aliaksandr. 2018. "Unrequited Love? The Hungarian Democrats' Relations with the Czechoslovak Authorities (1919-1932)." Hungarian Studies Review 45.1-2: 21-60.

Plumtree, James. 2018. "Charlemagne's Road, God's Threshing Floor: Comprehending the Role of Hungary in the First Crusade." Hungarian Studies 32.1: 1-26.

Pócs, Éva. 2018. "The Hungarian Táltos and the Shamanism of Pagan Hungarians. Questions and Hypotheses." Acta Ethnographica Hungarica 63.1: 149-196.

Postmus, Bouwe. 2018. "Gissing in Hungary." Gissing Journal 52.4: 21-24.

Rethelyi, Mari. 2018. "Good Writers, Bad Jews: the 'Jewish Question Among Hungarian Jewish Intellectuals of the Interwar Period." Journal of Modern Jewish Studies 17.2: 222-235.

Rus, Dorin-Ioan. 2018. "Peacetime Changes to the Landscape in Eighteenth-Century Transylvania: Attempts to Regulate the Mures River and to Eliminate Its Meanders in the Josephine Period." Hungarian Historical Review 7.3: 541-567.

Scheibner, Tamás and Kathleen Cioffi. 2018. "Archiving the Literature and Theater of Dissent: Beyond the Canon." The Handbook of COURAGE: Cultural Opposition and Its Heritage in Eastern Europe. Eds. Balázs Apor, Péter Apor and Sándor Horváth. Budapest: HAS, 2018: 307-28.

Schwartz, Agatha and Mythili Rajiva. 2018. "Haunting and the Aesthetics of Trauma in A Woman in Berlin and For Those Who Can Tell No Tales: Redefining Cultural Memory." Slavonica 23.2: 75-90.

Schwartz, Agatha. 2018. "Historical Trauma and Multidirectional Memory in the Vojvodina: László Végel's Neoplanta, avagy az Igéret Földje and Anna Friedrich's Miért? Warum?" Hungarian Studies Review 45.1-2: 61-82. 
Varga, Zsuzsanna. "Selected English-Language Bibliography of Interest for Hungarian Cultural Studies: 20182019." Hungarian Cultural Studies. e-Journal of the American Hungarian Educators Association, Volume 12 (2019) DOI: $10.5195 /$ ahea.2019.366

Schwartz, Agatha and Helga Thorson. 2017. "The Aesthetics of Change: Women Writers of the Austro-Hungarian Monarchy." Crossing Central Europe: Continuities and Transformations, 1900 and 2000. Eds. Carrie Smith-Prei and Helga Mitterbauer. Toronto: Toronto UP: $27-49$.

Schwartz, Agatha. 2016. "Austro-Hungarian Multiculturalism and Hybridity in Marie Eugenie delle Grazie's Short Prose." U carstvu reči - jezici i kulture. Zbornik u čast prof. dr Jovana Đukanovića / Im Reich der Wörter - Sprache(n) und Kultur(en)/Festschrift für Prof. Dr. Jovan Đukanović. Eds. Jelena Kostić-Tomović, Annette Đurović, Nikolina Zobenica and Branislav Ivanović. Belgrade: FOCUS - Forum za interkulturnu komunikaciju: 262-76.

Segesser, Daniel Marc. 2018. ''Fighting Where Nature Joins Forces with the Enemy': Nature, Living Conditions, and their Representation in the War in the Alps 1915-1918."

Hungarian Historical Review 7.3: 568-593.

Sepsi, Enikő. 2018. "On Bearing Witness to a Poetic Ritual: Robert Wilson's Deafman Glance as Seen by János Pilinszky.” Text \& Presentation, 2017: The Comparative Drama Conference Series. Ed. Jay Malarcher. Jefferson, NC: McFarland: 167-179. Sherwood, Peter. 2018. "Kossuth and Solidarity." Slavonic and East European Review 96.2 310-23.

Sherwood, Peter. 2017. '"I Have Passed by Several Persons Talking Latin in the Sreets": The Reverend William Coxe in Hungary in early 1778" 70 snippets to mark Ádám Nádasdy's 70th birthday. Ed. Péter Szigetvári. Budapest: Department of English Linguistics, Eötvös Loránd University. http://seas3.elte.hu/nadasdy70/sherwood.html

Smith, Camilla. 2018. "Was Nicht im 'Baedeker' Steht: Exploring Art, Mass Culture, and Antitourism in Weimar Germany." New German Critique 45.1: 207-245.

Sridharan, Preetham. 2018. "Agglutinating" a Family: Friedrich Max Müller and the Development of the Turanian Language Family Theory in Nineteenth-Century European Linguistics and Other Human Sciences. Dissertations and Theses. Paper 4341. Masters Thesis. https://pdxscholar.library.pdx.edu/cgi/viewcontent.cgi?article=5360\&context=open_access _etds

Stergar, Rok. 2018. "Introduction: Forum: The Adriatic, the Alps, and the Danube: Identities, Categories of Identification, and Identifications.” Austrian History Yearbook 49.1: 1722.

Sutton, Brett. R. 2018. Parallel Architecture, Parallel Acquisition: Cross-Linguistic Evidence from Nominal and Verbal Domains. PhD Dissertation. Georgetown University.

Szalai Anna, Rita Horváth and Gábor Balázs. 2007. Previously Unexplored Sources on the Holocaust in Hungary: A Selection from Jewish Periodicals, 1930-1944. Jerusalem: Yad Vashem Publications.

Szalóky, Melinda, Ágnes Matuska and András Szekfü. 2018. “From Iván Hevesy’s Aesthetics and Dramaturgy of the Film Play (1925), Part 2: The Structure and Image Construction of the Film Play." Cinema Journal 57.3: 61-76.

Szamosi, Barna. 2018. "Spencerian Influence on the Early Moral Philosophy of Ákos Pauler Regarding Racial and Gender Inequality." Hungarian Studies 32.1: 79-90.

Szczepaniak, Monika. 2018. “'Morden haben sie uns geschickt': Soldiers, Women and the Problem of Guilt in Literary Texts on the First World War." Philologie im Netz 85: 1-18. 
Varga, Zsuzsanna. "Selected English-Language Bibliography of Interest for Hungarian Cultural Studies: 20182019." Hungarian Cultural Studies. e-Journal of the American Hungarian Educators Association, Volume 12 (2019) DOI: $10.5195 /$ ahea.2019.366

Szekeres, Valéria. 2018. "Obstacles for Women in Technical Higher Education in Hungary." Gendering Postsocialism: Old Legacies and New Hierarchies. Eds. Ildikó AsztalosMorell and Julia Gradskova. London: Routledge: 211-230.

Szekfü, András. 2018. "Iván Hevesy and the Revolution of the Second Plan." Cinema Journal 57.3: 54-60.

Szénási, Zoltán. 2018. "Denominational Reception of Literary Modernity in Hungary Before 1920. ” Hungarian Cultural Studies 11: 23-31.

Szolláth, Dávid. 2018. "Inventory of Magic Textual Constructions of the Unnatural in Hungarian Postmodern Fiction." Neohelicon: Acta Comparationis Litterarum Universarum 45.2: 461-477.

Takševa, Tatjana and Agatha Schwartz. 2018. "Hybridity, Ethnicity and Nationhood: Legacies of Interethnic War, Wartime Rape, and the Potential for Bridging the Ethnic Divide in PostConflict Bosnia." National Identities 20.5: 463-480. http://dx.doi.org/10.1080/14608944.2017.1298580

Tamáska, Máté. 2018. “The Industrialization of the Danube Cityscape: Danube Ports During the Concurrent Urban Development of Vienna and Budapest 1829-1918." Journal of East Central European Studies 67.4: 552-577. https://www.zfoonline.de/index.php/zfo/article/view/13592/13334

Timmer, Andria D. 2016. Educating the Hungarian Roma: Non-Governmental Organisations and Minority Rights. Lanham, Lexington Books.

Tompa, Andrea. 2018. "Us and Them: Nationalism Staged." Theater 48.2: 47-63.

Toró, Tibor. 2018. "Ethnicization or de-Ethnicization? Hungarian Political Representation in the Romanian Parliament." Nationalities Papers 46.2: 219-236.

Török, Zsuzsa. 2018. "Notorius Beyond any Other European Woman of Her Generation: The Case of Count(ess) Sarolta/Sándor Vay." Slavonica 23.1: 53-69.

Turbucz, Dávid. 2018. "Miklós Horthy in Poland: Official Visit, Image of Charismatic Leader and His Leader Cult: The Hungarian Interpretation." Hungarian Studies 32.2: 291-304.

Ureczky, Eszter and Zsolt Győri. 2019. "Fluid Audio-Spatial Aesthetics and the Communalization of Popular Music in the Multi-Clip Movie Balaton Method." Studies in East European Cinema 10. 2: 175-192.

Valkola, Jarmo. 2018. "Miklós Jancsó's Historical Cinematic Spectacles and Moving Pictorial Figurations in a Hungarian Landscape a Study and a Phenomenological Perspective on Jancsó's Films of 1960s and 1970s." Hungarian Studies 32.1: 145-164. Vadas, András and Péter Szabó. 2018. "Not Seeing the Forest for the Trees? Ottoman-Hungarian Wars and Forest Resources." Hungarian Historical Review 7.3: 477-593.

Varga, Zsuzsanna. 2016. "Emília Kánya: Author, Editor, Educator.” Frauenbildung und Emanzipation in der Habsburger Monarchie. Der südslawische Raum und seine Wechselwirkung zu Wien, Prag und Budapest. Eds. Ilse Korotin and Vesela Tutavac. Wien: Praesens: 214-232. 
Varga, Zsuzsanna. "Selected English-Language Bibliography of Interest for Hungarian Cultural Studies: 2018-

2019." Hungarian Cultural Studies. e-Journal of the American Hungarian Educators Association, Volume 12 (2019) DOI: 10.5195/ahea.2019.366

Vasvári, Louise O. 2018. "Identity and Intergenerational Remembrance through Traumatic Culinary Nostalgia: Three Generations of Hungarians of Jewish Origin." Hungarian Cultural Studies 11: 57-77. https://ahea.pitt.edu/ojs/index.php/ahea/article/view/322

Vidács, Bea. 2018. "Blood Is Thicker than Water: Transformations in Strategies of Choosing Godparents in a Hungarian Village." Journal of Family History 43.1: 12-29.

Weitemeier, Bernd. 2018. "The Otherworld Revisited: A Late Sixteenth-Century German Text Witness of the Visiones Georgii and Its Illuminations." Medieval Translator/Traduire au Moyen Age 14: 465-483.

Zsila, Ágnes and Zsolt Demetrovics. 2018. "Icons of Self-Destruction: The Portrayal of Aggression and Abusive Behaviors in Band Slash Fiction.” The Darker Side of Slash Fan Fiction: Essays on Power, Consent and the Body. Ed. Ashton Spacey. Jefferson, NC: McFarland: 50-75. 